\title{
OVER PACHTCONTRACTEN.
}

Het merkwaardig artikel van den heer Hartog, in het Maartnummer, heeft zekerlijk veler aandacht getrokken, omdat het een onderwerp behandelt, waarbij onderscheidene belangen zijn gemoeid, terwijl toch de kennis van de vereischten zelden anders dan empirisch is. Het verruimen van den gexichtskring en het aanvoeren van nieuwe stoffe ter vergelijking, gelijk de heer $\mathrm{H}$. deed, is een prijselijk werk. Misschien kan het daarom zijn nut hebben aan die beschouwingen eenige aanteekeningen toe te voegen, ontleend aan den landbouw in Overfakkee.

Men aanvaardt in deze streken de losse landen na het blooten der schoof d. i. omstreeks September; weilanden in November en boomgaarden meestal ook terzelfden tijd, ofschoon ook wel kersmis als termijn voorkomt.

Eene bouwhoevè wordt in Mei betrokken, doch vooraf heeft de bewoner reeds ruimte in den stal, zoo noodig weide, moeten verstrekken voor de paarden van den opkomenden pachter, die het te aunvaarden land zelf in bezaai brengt.

Omtrent het al dan niet achterlaten van den mest schijnt geen algemeen gebruik te bestaan. Wie ze bij aanvaarding der hoeve vond, moet ze ook achterlaten bij scheiding; doch anders wordt de mestput op taxatie overgenomen.

De pachtceel behelst verder voorwaarden voor de oplevering; één deel eenjarige wei, éćn deel tweejarige, zooveel deelen klavers, zooveel witte of bruine stoppels. Deze bepaling van oplevering in stoppelvruchten wordt ook meestal aangetroffen bij de losse landen; en voor den verhuurder of nieuwen pachter wordt uitdrukkelijk het recht bedongen tijdig in die vruchten klaverzaad te zaaien, dat door den vertrekkende moet worden ondergewerkt en als eigen vrucht verzorgd.

Wat in Flakkee als "beneficic" bekend is, vormt een niet gering 
onderdeel bij nieuwe verpachting. Daartoe hehnort natnurlijk de mest, kunstweido, brak enz. Gewoonlijk wordt daarvan schatting opgemaakt door twee neutrale deskundigen.

Het laat zich begrijpen, dat in jaren waarin de warde van het land stijgt en iemand verlangt zijne huur over te dragen aan cen ander, onder deze beneficie ook meestal eene premie begrepen is om het land in handen te krijgen en meermalen wordt beneficie betaald voor dood mager, uitgezaaid land, alleen om te genieten van de vóór eenige jaren aaugegane en dus lagere pacht. Soms, wanneer dit al te zeer in 't, oog springt, bedingt de verpachter een deel daarvan voor zich.

Zoover mij bekend is kent men garfpacht niet, tenzij dan in 't klein, waar soms een knecht goed toebereid land voor uienteelt huurt van zijn baas, om de helft. Doch in geregelde pachtcontracten komt het niet voor, en het schijnt dan ook onvereenigbaar met de tegenwoordige verhoudingen tusschen landheer en landbouwer. De boer is gewoonlijk berekenend genoeg om de beteckenis van bet land voor zijne behoefte in geld te herleiden, en de landheer, dikwijls ver van zijne bezitting, zou maar zelden raad weten met de producten in natura De verrekening van de niet rechtstreeks rendeerende landerijen moet wel moeilijk zijn.

Ook het middel, door den heer Hartog aangewend, om de pachtsom op zekere vernuftige wijze afhankelijk te doen zijn van den marktprijs van eenig hoofdproduct - hier de tarwe - bereikt het doel van compensatie geenszins. Eerstens houdt het slechts rekening met een der factoren van 'slandbouwers verdienste, met den prijs namelijk; maar het verwaarloost den evenzeer belangrijken factor: de opbrengst. Voorts is het zeer moeilijk, bij een hoog ontwikkeld landbouwstelsel, dat zich meer en meer van uitsluitenden koornteelt gaat losmaken, eenig product als hoofd: product aan te wijzen. Onze boeren bestemmen gewoonlijk een stuk aardappels of uien om daarmee de pacht te betalen en speculeeren vrij aardig met de rest. Als waardemeter voor des bouwmans verdienste zou de prijs der tarwe - of van eenige vrucht bij uitsluiting van andere - onbruikbaar bevonden worden, en een vaste pachtsom in geld schijnt daarom verkieslijk.

Daarbij behoort ook eene uitdrukkelijke bepaling in het contract waarbij de pachter afstand doet van het voorrecht dat artt. 1628 en 1629 B. W. hem schenkt, ingeval van misgewas, droogte of overstrooming. Immers, het schijnt niet billijk - tenzij alleen voor het laatste geval waarbij de landheer de noodige maatregelen 
had kunnen verzuimen of tegenwerken - eene van de partijen nog te belasten met de mogelijke nadeelen, zonder dat evenredige voordeelen daartegen overstaan Dergelijke bepalingen waren verdedigbaar toen de verhouding van pachter tot eigenaar ecne meer afhankelijke was. De pachter was een arme kinkel, wien men 't levensonderhoud gunde op een stuk gronds; doch dergelijke toestanden zijn meestal gewijzigd en het schijnt niet noodig de herinnering daaraan te behouden.

Evenzoo gaat het met de vrijstelling, die door enkele eigenaren geheel vrijwillig geschonken wordt, gelijk dit plaats had in 't afgeloopen jaar. Zekerlijk legt die schenking een gunstig. getuigenis af van de edele bedoelingen dezer landheeren, doch het is zeker dat, na het wegnemen van de vrees voor slechte jaren, de door landbouwers uitgeloofde pachtprijs onredelijk hoog klimmen zal, want de kans op vrijstelling wordt dan met licht verklaarbaar optimisme, ten ruimste gedisconteerd; zoodat die ééne gunst den landman door overmoed ten verderve kan voeren. En waarom zou hem in zijn bedrijf een waarborg worden geschonken dien andere nijveren missen? Geen koopman krijgt vergoeding als de prijzen dalen na belangrijken inslag; geen visscher als de vangst slecht is; geen spoorweg als het verkeer zich op andere lijnen richt.

Zooals partijen thans staan, behooren zij te worden beschouwd al gelijken.

De voordeelen van langen pachttermijn worden hier zeer hoog geschat. Men aanvaardt landhoeven gewoonlijk voor 14 jaren, losse landen voor 10 jaren. De regel is dat pachtvernieuwing gesloten wordt drie jaren vór het eindigen van den termijn. Het belangrijke kapitaal dat de bouwman aan den grond toevertrouwt maakt die voorzorg dringend noodzakelijk, en de enkele landheeren die daarvan niet genoegzaam doordrongen zijn, ondervinden de schadelijke terugwerking op den pachtprijs.

Onderverhuring wordt niet toegestaan, ofschoon te dien aanzien nog al iets voorkomt, dat den verpachter onbekend blijft.

De heer H. heeft geene melding gemaakt van 't geen hij raadzaam acht bij den dood des pachters; toch is nauwkeurige bepaling daaromtrent wenschelijk, daar men niet weet in welke slechte handen het land bij versterf zou kunnen vervallen. Onze contracten behelzen de clausule dat de verpachter alsdan weder de vrije beschikking krijgt, mits uitkeerende de beneficie op schatting van twee neutrale deskundigen. Men gevoelt dat deze bepa- 
ling nog al bezwarend is, maar zij wordt verzacht door het gebruik om slechts bij dringende noodzakelijkheid hare scherpte te doen gevoelen. Immers: het is in 't belang van den landheer dat de pachters het land als het hunne beschouwen, en daar waar onderling vertrouwen heerscht, gaan de landerijen dan ook over van vader op zoon. Alles wat aan dit vertrouwen afbreuk doet, benadeelt den grond; de ware belangstelling blijft slechts bestaan bij een krachtigen band trsschen den grond en den bouwman.

Omtrent de cultuur schrijven de meeste pachtcontracten slechts weinig voor. De teelt van enkele, sterk roovende vruchten als slazaad, mosterdzaad enz. is verboden: ook het verbouwen van dezelfde vrucht twee jaren achter elkander op 't zelfde stuk; doch overigens laat men den landbouwer vrij, gelijk zulks behoort in het systeem dat hem beschouwt als den besten kenner van zijne eigene belangen. Dat die vrijheid zich niet uitstrekt tot de drie laatste jaren van den pachttermijn is begrijpelijk. De weilanden worden niet altijd zoo gunstig behandeld. Men eischt dikwijls dat de beweiding geschiede in verhouding van twee runderen op één paard, en deze bepaling is in de praktijk zóó bezwaarlijk dat zij meermalen wordt overtreden. Het tweemaal maaien van gras of klaver wordt slechts bij wijze van gunst toegestaan, Lucerne-klaver echter blijft vrij.

In den laatsten tijd is het noodig geworden eene nieuwe beperking in te voeren ten aanzien van den geoorloofden mest. Ofschoon de ondervinding of de wetenschap nog geene beslissende uitspraak hebben gedaan, bestaat er gegrond vermoeden dat de als "aanjagers" bekende hulpmeststoffen, als salpeter, keukenzout enz., den grond snel helpen uitputten; waarom dan ook, in de nieuwere huurcontracten, het gebruik daarvan af hankelijk wordt gesteld van de schriftelijke toestemming der verpachters. Men heeft nog wel de opmerking gemaakt dat ook de teelt van suikerbieten onder strenger toezicht moest worden gesteld, omdat zij gansch onnoodig veel humus medevoeren. Dit verlies zou voorkomen kunnen worden door de bepaling dat zij op het land zelf zouden moeten worden schoongemaakt: doch het is mij niet bekend dat dit verlangen in eene beschrevene bepaling is nedergeleg.d.

De verhuring geschiedt meestal ondershands. Niemand is onbekend met de grootere sommen, die men gewoonlijk bij publieke verpachting bedingt; maar de landheer, die belang heeft bij het bestaan van eene degelijke, soliede, redelijk bemiddelde boerenklasse, doet beter met zooveel mogelijk zijne eigene pachters te 
behouden en slechts enkele malen de publieke verpachting te horigen als anwijzende do maximum-pachtwaarde. Bij dit systeem vallen die enkele aangeboden partijtjes meestal ten deel aan doorgaans zeer ijverige, maar minder bemiddelde boertjes, die onophoudelijk gereed staan om te hemachtigen hetgeen uit de handen der groote boeren valt en den prikkel genoegzaam levendig houden.

Van de verbeteringen draagt de verpachter of eigenaar slechts zelden een deel. Voor zooverre zij algemeen zijn als b. v. bij stoomgemalen of grintwegen, vindt hij den last in de verhoogde polder-omslagen; voor de bijzondere wordt het enkele malen door versehil in de pacht gevonden. Bij aanleg of beharding van wegen betaalt de pachter gewoonlijk niets meer dan de rente van het kapitaal en verleent hij - bij zeldzame overeenstemming - spandiensten on voor de gedane uitgaaf is dan ook waarlijk de eigenaar genoegzaam beloond door de verhoogde waarde van het land.

Tet slotte veroorloof ik mij eene aanteekening, van meer algemeene strekking, op den aanhef van het opstel des heeren Hartog, waar beweerd wordt dat de meeste voordeelen van den grond kunnen getrokken worden waar de eigenaar bouwman is.

Het sehijnt mij toe dat deze stelling moet worden aangevuld met dit belangrijk beding: dat de eigenaar bovendien genoegzaam bemiddeld zij om een flink bedrijfskapitaal ter beschikking to houden. Bij de steeds hoogere eischen die het landbouwbedrijf stelt; bij het belangrijk kapitaal, dat in den vorm van draineering, mest, arbeid enz. enz. aan den grond wordt toevertrouwd, wordt het steeds moeilijk om eigenaar en landbouwer te gelijk te zijn. Hypotheken komen daarin slechts gebrekkig te gemoet, want de renten zijn meestal hoog, de voorschotten natuurlijk slechts gedeelten van 's lands waarde; de bepalingen bezwarend; aflossing dreigend $\left({ }^{*}\right)$ omdat er geen band bestaat tusschen geldschieter en geldnemer.

Uit een algemeen oekonomisch oogpunt schijnt het wenschelijk dat de boer zich vrijmake van landbezit, om met ruime hand den grond goed te doen; mits hij slechts, gelijk vooraf gemeld werd, voldoende zekerheid bezitte van de betrekking op zijn land

$\left(^{*}\right)$ Door het systeem bij de Hypotheekbanken in zwang, nl. af betaling door annuitciten waarin rente en aflossing begrepen is, waardoor de geldopmener dus tegen onverwachte oprordering is gewaurborgd, ('t geen niet belet dat hij, des rerkiezende, altijd kan aflossen) vervalt dit bezwanr ten cenenmale.

REn, 


\section{5}

niet willekeurig te verliezen. Het komt hier meermalen voor, dat de grond verkocht wordt onder beding dat de verkooper daarop pachter blijve tegen tamelijke rente. De onderhandeling geschiedt dan meestal zeer vlot.

Wie alleen de morcele zijde van dit vraagstuk beschouwt, zal allicht bejammeren dat de onafhankelijke boer een gebonden pachter wordt en daarin een bewijs van achteruitgang zien. Dat kan het wel zijp - maar meestal is 't zoo niet. Er is voor 't landbouwbedrijf een zegen in; want het is daarmede als met de warmte. Het kapitaal dat een rijke, anders in effecten, thans in land belegt, maakt een even groot kapitaal vrij, dat grootendeels voor den landbouw wordt benuttigd. Het is vreemd kapitaal dat binnen onze grenzen vruchten dragt, en wie zou dat willen afwijzen?

Middelharnis, 10 April '80.

C. J. H. v. D. ВrокK. 